81'1:165

811.163.41'373.612.2

https://doi.org/10.18485/kij.2021.68.2.4

ВАЛЕНТИНА М. ИЛЙ ${ }^{*}$

Универзитет у Београду

Филолошки факултет
Оригинални научни рад

Примљен: 25.10.2021.

Прихваћен: 08.11.2021.

\title{
АПСТРАКТУМИ ИСТИНА И ЛАЖ У САВРЕМЕНОМ СРПСКОМ ЈЕЗИКУ: КОНЦЕПТУАЛИЗАЦИЈА ЛАЖИ (когнитивнолингвистички приступ) ${ }^{1}$
}

\begin{abstract}
Рад представља други део истраживања у коме су апстрактне именице истина и лаж, које обележавају важну сферу човековог духовног живота, анализиране когнитивнолингвистичким методом концептуалне анализе на корпусу савременог српског језика. На почетку рада наведени су најважнији закључци у вези са концептом истине. У главном делу даје се преглед и анализа грађе, којом се долази до појмовних метафора и сценарија груписаних по различитим нивоима општости, који илуструју концептуализацију лАжи у савременом српском језику. Изводи се закључак и издвајају се кључне карактеристике обликовања овог појма у нашем когнитивном систему, а на самом крају се утврђују сличности и разлике концепата испитиваних именичких антонима.
\end{abstract}

Кључне речи: ЛАЖ, ИСтинА, апстрактум, концепт, појмовна метафора, концептуална анализа.

\section{1. Увод}

1.1. Когнитивнолингвистичка семантичка анализа апстрактума истина и лаж методом концептуалне анализе била је предмет нашег мастерског истраживања. У претходном раду детаљно су представљени теоријско-методолошки оквир, циљеви и корпус на коме је истраживање спроведено, етимологија и савремена значења истине и лажи, а затим и анализа концепта истинЕ (в. Илић 2020).

*valentina.ilic@fil.bg.ac.rs

${ }^{1}$ Рад представља скраћену верзију другог дела мастер рада Концептуализаичја апстрактних имениия истина $u$ лаж у савременом српском језику, који је одбрањен 30. септембра 2015. године (Комисија: проф. др Рајна Драгићевић (ментор) и проф. др Драгана Вељковић Станковић). Први део рада (концептуализација истинЕ) објављен је у часопису Књижевност и језик, LXVII/2 (2020), стр. 273-290. Овом приликом се објављује његов други део (наставак), посвећен концептуализацији лАжи.

Рад је урађен у оквиру пројекта Српски језик и његови ресурси: теорија, опис и примене (178006), који финансира Министарство просвете, науке и технолошког развоја Републике Србије. 
1.2. Главни закључци концепта истинЕ у савременом српском језику илустровани су од најопштијег, генеричког нивоа, па до најконкретнијих степена концептуализације. Подсетимо их се:

„Истина [се] у српском језику на генеричком нивоу концептуализације разуме као 1) ЕНТИТЕТ ИЛИ Као 2) ПОЈАВА.

(1) У слУчајУ ЕНТИТЕТА, она је тиПично САКРИВЕНА; може бИТИ У НАМА ИЛИ ИЗВАН НАС. Када је изван нас, мИ ЈоJ СтРЕмИмо. Истина је ЕНтитЕТ колИ СЕ КРЕЋЕ у вертикалном или хоризонталном смеру. Крајње инстанце вертикалне димензије означене су оријентационим метафорама истинА JE долЕ и истинА JE гоРЕ. Када је доле, истинА у вертикалном кретању ТЕЖИ ДА ИЗБИЈЕ НА ПОВРШИНУ. Када је Горе, ОНА ЈЕ У ВЛАСТИ БОГА ИЛИ БОГ СА̂м, Те У ЊУ ВЕРУЈЕМО ИЛИ НЕ ВЕРУЈЕМО. На ЗемљИ се реалИзУје У видУ БОЖЈЕ ПРАВДЕ. У хоризонталном кретањУ она ИДЕ ИСПРЕД НАС, А МИ ЈЕ СУСТИЖЕМО.

(1.1) Даља конкретизација ЕнтитетА упућује да истинА може бити живо БиЋЕ, мАТЕРИЈА ИЛИ ПРЕДМЕТ. Као ЖИВО БИЋЕ, ИСТИНА је чОВЕК/ОСОБА, БИљКА ИЛИ ЖИВОТИњА. У ПРвом случају, као осоБА, може се даље конкретизовати као воъА или господАР. Виђена као МАТЕРИЈА, ИСТИНА ИМа ТЕЖИНУ (ОНА ЈЕ ТЕРЕТ) И ТОПЛОТУ (ХЛАДНА ИЛИ ВРУЋА), ХРАНЉИВА ЈЕ, алИ НЕПРИЈАТНОГ УКУСА, ТЕЧНА И БИСТРА. Схваћена као ПРЕДМЕТ, оПисују је следеће карактеристике предметности: старост, величина, припадање, (не)дељивост. Тај предмет можЕ дА ПОВРЕДИ, ТЕ ГА ЗАОБИЛАЗИМО. Са дрУГе стране, она је тИПично стамена ГРАБЕВИНА, а У ширем СМИСЛУ САДРЖАТЕЉ. МОЖе бИТИ И САДРЖАНИ ОБЈЕКАТ - У РЕЧИ ИЛИ ИСКАЗУ.

(2) ИСтИНА ЈЕ И ФИзИчКА ПОЈАВА, будући да је карактерише време/трајање (вечНА JE), можемо је осетити чулима, али и интуитивно спознавати (ОСЕЋАмО JE) и испитивати је (МОЖЕМО ЈЕ САЗНАВАТИ И ПРОУчАВАТИ). На НИЖем нивоу аПстракције тиПично се концеПтуализује као светлост или СилА" (Илић 2020: 287).

1.3. У овом раду, на основу репрезентативних примера из грађе довољних да потврде регистроване појмовне метафоре, осветљавамо концептуализацију лАжи, те ова два концепта, у завршници, поредимо и одговарамо на истраживачка питања, која су се наметнула на почетку истраживања: ${ }^{2}$

„Да ли су концепти истинЕ и лАжи можда подударни или се разликују? Ако се разликују - да ли су те разлике у некој вези са нивоом општости појмовних метафора? Да ли су чињенице о антонимима које се тичу семантичког саодношења и разликовања једне семе у неком симетричном односу са појмовним метафорама које описују концепте ових појмова? Најзад, да ли је овде реч о правим антонимима?" (Илић 2020: 276).

\section{2. Градијентност семантике лажи}

2.1. Будући да има веома важан статус у човековом духовном животу, лаж (са својим опонентом - истином) била је и остала предмет интересовања многих филозофа, теолога, психолога, социолога, антрополога, филолога (Черњејко 1997; Шкембер 2012; Ван Дитмарх и др. 2020: 466-484 и др).

${ }^{2}$ Овај рад, дакле, треба читати као наставак поменутог рада, насловљеног Апстрактуми истина $и$ лаж у савременом српском језику: концептуализаџија истинЕ (когнитивнолингвистички nристуn). Због уштеде простора, овде нисмо понављали методологију истраживања, образложење корпуса, понеке скраћенице и сл. За све евентуалне недоумице треба консултовати први део истраживања: Илић 2020. 
2.2. Са Августиновим списима О лажи и Против лажи питање лагања прешло је у хришћанство. Он закључује да је свако намерно казивање нечег лажног нужно и грех (осим ако није реч о шали). У његовим списима проналази се једно од првих разврставања лажи на основу критеријума тежине греха: 1) Лажи у верском учењу; 2) Лажи које шкоде другима, а никоме не помажу; 3) Лажи које шкоде другима, а некоме помажу; 4) Лажи изречене из задовољства да се лаже; 5) Лажи изречене да би се „други разгалили у милозвучној беседи”; 6) Лажи које никоме не шкоде, а некоме помажу; 7) Лажи које никоме не шкоде, а спасавају нечији живот; 8) Лажи које никоме не шкоде, а спасавају нечију „чистоту”. Августинова есхатолошка етика не допушта лаж ни у једној прилици. Ако помоћу лажи спасавамо чак и живот пријатеља, губимо духовну бесмртност; ништа није вредно губитка истине. Надовезујући се, Тома Аквински ће рећи: никад не бирајмо лаж, и увек будимо спремни да умремо за истину (према Кант и Констан 2008: 81).

2.3. Амерички лингвисти Линда Колман и Паул Кеј (1981) семантичким методом анализе прототипа показали су да прототипична лаж има три елемента:

1) говорник верује да је исказ нетачан;

2) говорник има намеру да превари саговорника и

3) исказ је заиста нетачан.

Њихово експериментално истраживање показало је да је за изворне говорнике енглеског језика први елемент (веровање у нетачност) најважнији за појам лажи, наредни елемент по значају је постојање намере да се саговорник превари, а најмање је важна стварна (фактуелна) нетачност исказа. Постоје, дакле, лажи за које важе сва три елемента, па су оне прототипичне, али и оне којима недостаје неко од наведених критеријалних обележја или поседују неки нови елемент, што их чини више или мање типичним. Најзад, оно тврђење које не поседује ниједан од три елемента, не може бити лаж. Оваква градијентност појма лажи у когнитивној семантици чини се да кореспондира, премда грубо, са наведеном филозофско-теолошком Августиновом типологијом, која приказује скалу лажи са аспекта снаге греха који се чини њеним изговарањем.

2.4. Како тврди Ив Свитсер (1987), строго одређење појма лажи условљено је културолошким контекстом. Наиме, свака лаж би се, према овој ауторки, могла кратко и једноставно одредити као нетачни исказ (енгл. false statement). То значење је језгрено и готово универзално. Њему се придодаје значење које креира културна матрица сходно својим моралним, филозофским и друштвеним схватањима. Културни модели се у том погледу међусобно веома разликују. Свитсер наводи неколико примера нама далеких култура које на различите начине, на пример, оцењују ко сме а ко не сме никада да буде преварен или повређен. Различити културни миљеи имају друкчије моделе информационих размена, схватања дискурса и моћи, који генеришу и баштине „богат контекст који чини употребу лажи много сложенијом него што показује [њена] једноставна дефиниција" (Свитсер 1987: 62-63). 
2.5. Другост култура и њихових погледа, како примећује Свитсер (idem: 50), сликовито илуструје Џ. Свифт у Гуливеровим путовањима. Нашавши се у далекој земљи Хуинхма, Гуливер се трудио да научи њихов језик, како би се могао споразумевати са домороцима. У језику Хуинхма не постоји реч аналогна нашим речима лаж или превара, већ само израз - „ствари које нису”, који заправо одговара најједноставнијој (базичној) семантици лажи коју даје И. Свитсер. Њихов поглед на свет и социјални односи чинили су да Хуинхми немају потребу за речју која ће означити свесно извртање истине са намером да саговорник буде преварен. О томе говори и сам Лемјуел Гуливер:

„Сећам се како је мој господар, који је иначе необично брзо схватао, тешко успео да разуме шта мислим кад сам у нашим честим разговорима о природи људи у другим деловима света имао прилике да споменем лагање и извртање истине. Он је, наиме, овако судио: језик је за то да један другог разумемо и да се обавестимо о чињеницама; сад, ако неко каже ствар која није, ти циљеви су осујећени, јер се онда заправо не може рећи да сам га разумео, и не само што нисам добио обавештење, него сам стављен у горе стање но што је незнање, јер сам наведен да верујем да је нешто црно кад је бело, кратко кад је дугачко" (Свифт 2002: 347-348).

Хуинхми, дакле, за разлику од Гуливера, немају изграђен социокултурни контекст и дискурсни модел који би им помогли да разликују неистину (као пуку нетачност) од лажи (као интенције да се саговорник обмане). Овај пример врло сликовито упућује на чињеницу да се неистина и лаж не могу сматрати правим синонимима, а отуда ни једнако алтернативним, правим антонимима именице истина.

2.6. Наведени сегмент епизоде из свевременог романа за децу не представља само пуку пишчеву фикцију већ има свој пандан у стварности, што потврђују и нека савремена лингвокултуролошка лексичкосемантичка испитивања индонежанских дијалеката. ${ }^{3}$ Према једном истраживању (Адха 2020), у коме су испитивани наведени елементи прототипичне лажи међу индонежанским изворним говорницима, показано је да је најважнији критеријум који су Колман и Кеј (1981: 35) навели - веровање у нетачност исказа - за индонежанску културу сасвим ирелевантан. На првом месту је управо „ствар која није”, тј. фактуелна нетачност, коју су амерички аутори навели као најмање важну, док је на другом месту намера да се саговорнику не каже истина (Адха 2020: 21-22). Овај и многи други примери указују да је прототип лажи варијабилан у зависности од културолошке матрице. Ипак, којим год елементима да је прототип лажи одређен, она је у већини култура појам меких граница, у који, поред прототипичног, улазе и мање типични примери (Ејчисон 1987: 57).

2.7. Већ на основу наведеног закључујемо да је семантика апстрактума лаж разуђенија и флуиднија од семантике истине. У наредној тачки ћемо представити како се у савременом српском језику концептуализује лаж, тј. које појмовне

${ }^{3}$ Одабрали смо истраживања језика Индонежана, будући да би земља Хуинхма, иако плод уметничке фикције и непрецизно територијално одређена, на основу других географских назнака из романа, највероватније била на јужној Земљиној полулопти, у Индијском океану. 
метафоре описују њено поимање, и у каквом односу стоје ова два - за човеков духовни живот - фундаментална концепта.

\section{3. Концептуализација лАжи - преглед и анализа грађе}

3.1. Анализом корпуса (дефинисаног у првом делу истраживања, в. Илић 2020: 275) долази се до шездесетак појмовних метафора, које илуструју концептуализацију лАжи, што је приближно једнако броју појмовних метафора идентификованих у анализи концепта истине (idem: 280). Метафоре и сценарији до којих смо дошли на основу великог броја примера показују да се на генеричком, најосновнијем нивоу лАж концептуализује на исти начин као и истинА. Реч је о Двема онтолошким појмовним метафорама: I) ЛАЖ ЈЕ ЕНтИтЕТ и II) ЛАЖ ЈЕ ПОЈАвА. Њих потврђује највећи број примера, који истовремено указују и на више, конкретније нивое концептуализације.

3.1.1. ЛАЖ ЈЕ ЕНТИТЕТ КОЈИ СЕ ТРАНСФОРМИШЕ (пр. Лаж је као феникс а на ствараоиима је да је вечно демаскирају (ЕКор); ...да је истина једна и јединствена, док се лаж јавља у много различитих облика (ЕКор)). Ову појмовну метафору потврђују поједини примери синонима придева лажан: претворан/ притворан (пр. Мало га је изненадио Ружићев претворни тон (Лалевић 2004)), превртљљив: „што се преврће на једну, па на другу страну, на лице, па на наличје” (idem), дволичан: „ко се показује час с једним, час с другим лицем” (idem). Синоними лексеме лаж код П. Ћосића (2007) имају и овакав облик: окретање, извртање истине.

Појам трансформације углавном значи промену форме, облика, док суштина датом ентитету остаје иста. У том процесу лАж (ПостА)ЈЕ ЕНТИТЕТ коЈИ личИ НА Истину (пр. Био је принуђен да лаж приказује као истину (ЕКор); патворен: „вештачки [...] супротно истинитоме, али налик њему по изради и облику” (Лалевић 2004); тобожюи: „који се само такав представља а није у ствари, само се чини таквим” (idem)). Виши степен трансформације доноси крупне, готово корените измене, па отуда лАж ПостАЈЕ истинА (пр. лаж је постала истина (ЕКор); ...ако лаж поновиш довољан број пута, она постаје стварност (ЕКор)).

3.1.2. ЛАЖ се још може концептуализовати као ЕНТИТЕТ КОЈИ СЕ НАДМЕЋЕ у ТРцИ СА ИСТИНОм (пр. Лаж је заузела место истине (ЕКор); ...с тим што је лаж увек за један корак испред истине (ЕКор)). КРЕТАњЕ ЛАЖИ може се Поимати понекад као кружно, а на такву метафору указује идиосинкратички пример Они су често „уљуљкани” у вртлогу сопствених лажи (ЕКор).

Са друге стране, ЛАЖ И ИСТИНА СУ ДВЕ КРАЈњЕ ИНСТАНЦЕ НА ЈЕДНОМ КОНтинууму (пр. Ако ништа друго, лаж им је служила као полазна тачка, коју су после, кад би сазнали истину, лако одбацивали (ЕКор); једна од синонимних форми за лаж је у Речнику синонима П. Ћосића (2007) и удаљавање од истине (2007)). Наведена синтагма наводи нас да претходну метафору проширимо још 
Двема сродним метафорама: ЛАЖ ЈЕ ДАЛЕКО ОД ИСТИНЕ. БИТИ ДАљЕ ОД ИСТИНЕ ЈЕ БИТИ БЛИЖЕ ЛАЖИ.

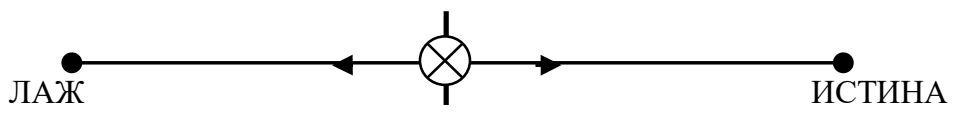

3.1.3. Појмовна метафора лАж ЈЕ ЕНтитЕТ на првој следећој равни конкретизације на замишљеној вертикалној скали конкретно-апстрактно концептуаЛИЗУје се исто Као И ИСТИНА: ЛАЖ ЈЕ 1) ЖИВО БИЋЕ, 2) МАТЕРИЈА И 3) ПРЕДМЕТ.

1) У корпусу је знатан број примера који потврђују анимистичку црту у поимању лАжи (пр. ...лаж и насиље узајамно живе у најприроднијој вези (ЕКор); Само лаж живи на правилима закључивања (ЕКор); ...а делимичне истине су најжилавије лажи (ЕКор)).

a) Највише примера из наведене скупине метафора упућују на метафору ЛАЖ ЈЕ ОСОБА, која је заправо персонификација лАжи (пр. изр. гола лаж (РСАНУ, РМС); изр. где лаж руча ту не вечера (РСАНУ, РМС); изр. лаж_кратке ноге има (РСАНУ) / у лажи су кратке ноге (РСАНУ, РМС, РCJ); ${ }^{4}$...да та лаж може мирне душе и дигнуте главе да уће у историју (ЕКор)). Да је ЛАж осОБА, упућују и атрибути који одређују именицу лаж, а типично је реч о придевима којима се квалификују особе: очајничка, бедна, жестока, безочна, глупа, дрска, понижавајућа, пакосна, безобзирна, нарциисоидна, бестидна, ичинична, лукава, осиона, злонамерна, подмукла, гнусна, срамна (ЕКор). Видимо да сви наведени придеви говоре да је у питању осоБА СА НЕГАТИвНИм осоБИНАмА. Много је мање придева којима се означава нека позитивна особина: пријатна, безазлена, хумана, суптилна, племенита, чиста. Из ове групе придева сви упућују на мање тиПИчну ЛАЖ, која је МАЛА и која чак МОЖЕ НЕКОМЕ ПОМОЋИ. ЈеДИНо се од њИХ разликује чиста лаж (= права лаж), што је у ствари ВЕЛИКА И ТЕШКА ЛАж. ${ }^{5}$ Негативну квалификацију лАжи одсликава и појмовна метафора лАЖ живи у ПРОСТОРУ МРАЧНОГ И ПРљАВОГ (Пр. Лажи су брзо изашле на светло дана (ЕКор); ...док истерују лаж на чистину (ЕКор); Не каљај се лажима (ЕКор)). За разлику од овога, видели смо да је истиНА чИСТА и свЕТЛА (ИЛић 2020: 285-286).

б) На основу неких деривата именице лаж из РСАНУ можемо закључити да је ЛАЖ ОСОБА коЈА СЕ воЛИ иЛИ мРзи: лажољубаи - „онај који воли лаж, лажљивац”; лажсомзаи - „онај који мрзи лаж, који се противи лажи”. ${ }^{6}$

${ }^{4}$ Наведени изрази: где лаж руча ту не вечера, лаж кратке ноге има / у лажи су кратке ноге говоре и о још једној метафори ЛАЖИ, а тиче се њене КРАТКОТРАЈНОСТИ, НЕСТАЛНОСТИ. Због тога ћемо их и касније уврстити у примере који потврђују ову метафору.

${ }^{5}$ Овде ћемо додати да поједини придевски атрибути указују на то у којој се сфери лажи „крећу и срећу", па тако у електронском корпусу налазимо: филмска лаж, политичка, друштвена, медијска, предизборна. Више различитих атрибута уз именицу лаж који упућују на јавни друштвени живот говоре нам о степену заступљености лажи у њему.

${ }^{6}$ Из ових примера се, додуше, може извести и метафора која је за степен општија: ЛАЖ ЈЕ ЕНТИТЕТ КОЈИ СЕ ВОЛИ ИЛИ МРЗИ. 
в) Конкретније од ОСОБЕ - ЛАЖ ЈЕ ВОЂА (пр. ...лаж која ме је уводила у његов табор (ЕКор)), а може се схватити и као господАР (пр. ... у земљи у којој је владала лаж (ЕКор); ...бирајући истину и правду, уместо потчињавања лажима (ЕКор)). Многи од примера показују да се лАж поима и као чудовиштЕ (пр. изр. репата лаж (РСАНУ, РМС); Ту ластују... неколико мјесеци, пуштајући репате лажи по свим вјетровима (РСАНУ); опипљиву многоглаву лаж пред очима и на домаку руку (ЕКор); ...да је иела хајка последица монструозне лажи (ЕКор)). У том контексту, можемо извести и метафору ЛАЖ ЈЕ НЕПРИЈАТЕљ (Пр. ...као $u$ одлучна борба против лажи (ЕКор); Реч је о лажима које могу бити опасне за све (ЕКор); Лажи су однеле велику победу (ЕКор)). Као таква, ЛАж изАзивА страх (пр. Једном сте негде изјавили да вас највише у животу узнемирује лаж (ЕКор); Лаж га је ужасавала (ЕКор)).

г) На основу прегледаног корпуса могу се издвојити још две метафоре које се тичу ЛАЖИ Као ЖИвОГ БИЋА. То су: ЛАЖ ЈЕ ПТИЦА (пр. Лаж сасвим природно излете из ьегових уста (ЕКор); ...док женама неистина „излети” само три пута у току дана (ЕКор)) и ЛАЖ ЈЕ БИљКА (Пр. Пошто се у модерним друштвима није примила лаж о томе да се сукоби могу решити (ЕКор); ...nолитике која је сејањем лажи о великосрпској хегемонији (ЕКор); ... накалемљене лажи од стране победника (ЕКор)).

2) Постварење лАжи у нашој свести илуструје немали број примера на основу којих се долази до метафоре лАЖ ЈЕ МАТЕРИЈА (пр. До дана данашњег нису скинуте наслаге лажи (ЕКор); Ништа друго и не ради, него се затрпава лажима (ЕКор); а око њега је био мук гомиле и истегнута, лепљива лаж (ЕКор)).

а) Као врста материје, лАЖ ЈЕ тЕчност (пр. ...а све зато, ито други мутти лажи (РСАНУ); ...Слатка чаша лажи (РСАНУ, РМС); ...људи који су огрезли у лажи (ЕКор); ...и опија се лажима (ЕКор); мунитва - „У народном говору [jе] као неко мућкање” (Лалевић 2004)). Обично је мутна (пр. ...а лаж непрозирна, не пропушта светлост ни поглед (ЕКор); ...а другим оком не видимо кроз лаж ни педаљ и тај поглед не може даље (ЕКор)), а уколико је ПРОзИРНА, НЕЋЕ оПСТАТИ (пр. ...да би лаж била и сувише провидна за юега (ЕКор); Лажуюати значи лагати тако провидно да се лако примети (РСАНУ)).

На основу примера може се закључити да није у питању само прозиРнА ТЕЧНОСТ, већ ПРОЗИРНЕ ЛАЖИ МОГУ бИТИ И ПРЕДМЕТИ. Такве ЛажИ КоНЦеПтУаЛИЗУјемо као НЕСТАЛНЕ И БЕЗАЗЛЕНЕ. С тим У везИ, Што ћемо видети касније, ЛАЖ се концептуализује и као ПлитКА ТЕчност, што је опет у вези са близином дна, до којег се лако и брзо долази. Дакле, као да нА днУ лАжи лЕжи истинА. Питање је само можемо Ли до њега допрети. ПРОВИДНЕ ЛАЖИ НЕСТАЛНЕ СУ, МАЛЕ И БЕЗАЗЛЕНЕ. ТРАНСПАРЕНТНОСТ И ЈАСНОСТ СУ КараКТерИстИКе ИСТИНЕ, а аКО ИХ ЛАЖ поседује, она не може бити типична, па се до онога што је под њом и што она скрива - истинА - лако и брзо допре.

б) Једна од метафора са највећим бројем потврда јесте лАЖ ЈЕ ХРАНА (пр. изр. пресна лаж (РСАНУ, РМС, РСЈ); Да ли је могуће да сви ови људи мирно гутају такву лаж? (ЕКор); Лаж је, међутим, зачињена Настићевим смехом, ис- 
падала само половична (ЕКор); Прича је стизала причу, лаж је досољавала лаж (ЕКор); ...апсолутизам који врви од бајатих лажи (ЕКор); масна лаж (ЕКор); слатке лажи (ЕКор); жвака, жарг. (Ћосић 2007)). Одавде закључујемо да је лАж ХРАНА КОЈА ЈЕ ЗАЧИњЕНА, СЛАНА (ПОНЕКАД СЛАТКА) И МАСНА. СЕРВИРА НАМ СЕ И МИ ЈЕ ГУТАМО. СТАРЕ ЛАЖИ СУ БАЈАТЕ. ${ }^{7}$

в) Најзад, будући материјална, ЛАЖ ЈЕ ТЕРЕТ (пр. ...nоследња јој је лаж била и најтежа (ЕКор); ...где ће притисак на юих бити знатно већи, са новим лажима (ЕКор); ситна, мала лаж, лака (Лалевић 2004 - објашњење уз синоним лагаpuјa)). У раду о истини показали смо да се и она концептуализује као тЕРЕТ (пр. Својим сународницима је говорио покашто тешке истине о богатству (ЕКор); а овде можемо додати и примере Његову искреност је тешко поднела; Тешко јој је пала истина коју је чула) (Илић 2020: 282). Дакле, оне истинЕ које су ВЕЛИКЕ И ЗНАЧАЈНЕ, ОНе СУ ТЕШКЕ И чеСТО МОГУ ДА НАС ПОВРЕДЕ. ТО СУ НеПОВОљНе ИСТИНе ПО ПрИМаОЦа. ТЕЖИНА ЛАЖИ ДИРЕКТНО ЈЕ ПРОПОРЦИОНАЛНА ТЕЖИНИ ИСТИНЕ КОЈУ КРИЈЕ. ШТО ЈЕ ВЕЋА И ТЕЖА ИСТИНА, ТО ЈЕ ВЕЋА И ТЕЖА ЛАЖ. РаЗЛИКа је У томе ШТо У ТИПичном случајУ ТЕРЕТ неповољне иСТИНЕ подноси онај који је прима/чује, док тЕРЕТ ЛАЖи носи онај који је производи, а када се она открије, тај терет се преноси (и) на примаоца. Уколико лАж крије повољну истину, њен терет носи само њен прималац; услед разоткривања такве лАжи следи растерећење (нпр. лаж: Она је и даље болесна. $\rightarrow$ истина: Она је оздравила.).

3) Скуп појмовних метафора који упућује на опРЕдмЕЋЕНост лАжи у нашем мишљењу је најразуђенији. Неки од примера ове полазне метафоре (ЛАж ЈЕ ПРЕДМЕТ) су: ...увек је морала протурити ту малену лаж (ЕКор); Многе лажи из иностранства разбиле су се у парампарчад (ЕКор); Ништа није наше осим варке, зато се чврсто држимо за юу (Лалевић 2004). Као и свака предметност, она се може држати, разбити, превртати, извртати, што значи да има своју спољашњост и унутрашњост; предмет, за разлику од материје, има јасне границе и у простору се не простире дисперзно. Отуда су предмети бројиви и могу се узети у апсолутној целини (Илић 2020: 283).

а) ВИШЕ ЛАЖИ САЧИњАВАЈУ НИЗ (Пр. ...само лаж до лажи (ЕКор); ...jош једна у низу обмана и лажи (ЕКор)), па их отуда мОжЕМо изБРОЈАТИ (пр. ...nрва лаж коју ћете пронаћи у овом тексту (ЕКор); ...nоследюа лаж (ЕКор); ...дневно изговоре у просеку шест лажи (ЕКор)).

б) ЛАЖ ЈЕ ВЕЛИКА (пр. ...почели су ту велику лаж да растурају (ЕКор); ...изрекао [је] овако крупну лаж (ЕКор)), мАЛА (пр. ...иапнула му ту малу лаж (ЕКор); Ниси способан ни за малену лаж (ЕКор); лагарија, лагуикање - „ситна,

\footnotetext{
${ }^{7}$ Ово виђење лАжи као ХРАнЕ Д. Мршевић-Радовић (2008а: 49) сматра илустративним примером антропоцентризма: духовне потребе се представљају као физичке (физиолошке). Нарочито је интересантан глагол досољавати, који значи изношење нетачности, претеривање. Међутим, потпуно изостављање соли мотивише значење говорити без имало памети, измишљати, те со чини ствари смисленијим: уп. солити некоме памет. „Зато уз истину не стоје епитети ни 'слана' ни 'неслана', ни 'посољена', јер је истина (већ) мудра, а лаж остаје или 'пресољена' (претерана) или 'неслана' (глупа)".
} 
мала лаж, лака" (Лалевић 2004); дем. и хип. лажица (РСАНУ) ${ }^{8}$ ), СТАРА или новА (пр. Стара лаж и уобичајени поклон до земље (ЕКор); ...са новим лажима и лажним доказима (ЕКор)).

в) ЛАЖ ЈЕ САКРИВЕНА (пр. Долазак кнеза Долгоруког у Србију беше одиста један сунчани зрачак, који за тренутак... лаж и клевету обелодани (РСАНУ); ...већ се веома боји да се ту крије лаж (ЕКор); ...заборављајући да се лаж брзо разоткрије (ЕКор)), али када се открије, ЛАЖ ВИДИМО ЈЕР ЈЕ ПРЕД НАМА (пр. И у стиду што се очита лаж прихвата са смерношћу и захвалношћу (ЕКор); ...флагрантна лаж, за коју неко мора да одговара [лат. flagrans - 1. који гори, ватрен, жесток; 2. очевидан, очит, који боде очи, отворен, несумњив (Вујаклија ${ }^{92006)]}$ (ЕКор); То је ноторна лаж [лат. noscere - упознати, познати; notorius - општепознат, јаван (Вујаклија ${ }^{92006)] ~(Е К о р)) . ~}$

г) Као што смо имали прилике да видимо у вези са истином (Илић 2020: 283), тако и за ЛАЖ можемо рећи да је ПРЕДМЕТ КОЈИ СЕ ПОСЕДУЈЕ (пр. .... лаж била би откривена (ЕКор); Немогућност да препознамо туђу лаж (ЕКор); Врати ми моје лажи (ЕКор)).

д) Као ПРЕДМЕТ, ЛАЖ Може бИТИ И обојеНа: ШАРЕНА, БЕЛА ИЛИ ЦРНА. СваКа од ових боја упућује на неку од карактеристика лажи. ЛАЖ ЈЕ ШАРЕНА (пр. Сада ће ти мајка доћи и донијет ти ширену лаж (РСАНУ); Живот је шарена лажа $($ РСАНУ) $\rightarrow \rightarrow$ шарати - „1. а повлачити црте, линије по нечему, 2. украшавати, улепшавати шарама (обично бојом) [...] 4. не говорити искрено, лагати, извлачити се, варати”; щиарен - „1. а. који је од више боја, разнобојан [...] 3. неискрен; непоуздан, сумњив" (РМС). Оно што је шарено, привлачно је и наоко позитивно, па отуда може лако да завара. Оно што је шарено, то је премазано разним бојама (уп. изр. премазан свим бојама - „врло препреден, лукав”); на тај начин мења се спољашњи изглед предмета: прикрива се, маскира и прерушава, а предмет се представља какав заправо није (уп. мазати, мастити, фарбати - „лагати, варати"). ${ }^{9}$ ЛАЖ ЈЕ БЕЛА (пр. беле лажси су за његово добро (ЕКор)) $\rightarrow$ Једно од фигуративних значења придева бео је и ,чедан, невин; светао, частан” (РМС). Када се овај придев употреби да квалификује лаж, тада упућује на БЕзАзЛЕНУ, СитнУ и вероватно изречену лаж зарад неког вишег циља. ТАКВА ЛАж НЕ шкодИ никоМе И ЛАКО СЕ ОТКРИВА. ВИДеЛИ СМО Да Те ЛАЖИ МОГУ бИТИ И БЕЗБОЈНЕ, ОДНОсНО ПРОзИРнЕ. У том случају је реч о мање типичним лажима. ЛАЖ ЈЕ ЦРНА (пр. ...говорећи му такве ирне лажи [да их је једва поднео] (ЕКор)) $\rightarrow$ Поред основног значења придева црн, ,који је боје угљена или чађи”, у РМС проналазимо и ова значења: „нечист, прљав, замазан; фиг. тежак, мучан, тешко подношљив; мрзак, одвратан, кобан, злокобан”, а такође је наведено да се овај придев користи и ,уз именице које значе нешто зло, неповољно, негативно: врло велик, тежак”. Отуда

\footnotetext{
${ }^{8}$ Као и у случају истине, ни овде не проналазимо аугментатив.

${ }^{9}$ У вези са способношћу да промени спољашњи изглед неког ентитета, ЛАЖ ЈЕ МАСКА (или ПлАшт) (пр. ...какву лаж човек на себе навлачи (ЕКор); ...на ствараочима је да [лаж] вечно демаcKupajy (EKop)).
} 
је транспарентно због чега се поједине лАЖи концептуализују као цРнЕ: то су ОНе ВЕЛИКЕ ЛАЖИ, КОЈЕ ТЕШКО ПОДНОСИМО И КОЈЕ ПО НАС МОГУ БИТИ КОБНЕ.

ђ) Поједини примери из корпуса указују да се лАж често концептуализује у виду зАмРШЕНИх нити (пр. ...у овом неразмрсивом клупку лажи (ЕКор); ...морао је још више да се упетља у сопствену мрежу лажи (ЕКор); У ткиво тачних вести уткивале су се тако и нити лажи (ЕКор); сплетка [од плести - „савијајући, превијајући што уско и дугачко (гранчице, пруће, траке, нити и сл.) састављати у једну целину”, отуда и „спремати, удешавати, смишљати нешто (обично тајно) да се коме нанесе штета, увреда”, РМС]; петљьарија, фам. [од петљь - „замка која се прави од нити при плетењу”, РМС] (Ћосић 2007)).

е) БУДУћи да је ЛАЖ ПредМеТ којИ је МАСКИРАН, ОБОЈЕН, оТУДа ИЗВЕШТАЧЕН, стиче се утисак као да ју је предано планирало и обликовало много људи и низ машина. На основу примера из корпуса изводи се и појмовна метафора ЛАж ЈЕ ПРЕДМЕТ КОЈИ СЕ ПРОИЗВОДИ У ФАБРИЦИ (Пр. ...преносећи једну такву фабриковану лаж (ЕКор); ...сматраћемо да је ово још једна исфабрикована лаж (ЕКор)). Природно је да јавност тражи истину у вестима, међутим, бројне медијске куће, умесно и служећи се разним триковима, истину пакуjy и изврћу. Институције које учествују у оваквим пословима називају се „фабрикама лажи”. Овде се јасно успоставља још један контраст према истини: лАж је артифицијелна, конструисана, промишљена, а истинА природна и постоји per se.

ПОШТО је СТВОРЕНА У ФАБРИЦИ, ЛАЖ ЈЕ РОБА КОЈА ИМА ЦЕНУ (Пр. ОНи копају земљу, а ја се бијем по памети: како ћу се од юи озбавити и какву ћу им лаж продати (РСАНУ)). Интересантно је да ЦЕНУ ЛАЖИ ПЛАЋАМО КАДА ЈЕ ПРОДАМО (пр. Лаж се скупо плаћа [платити - фиг. „имати, искусити, осетити неугодне последице због чега (каквог поступка, пропуста, дела и сл. свога или неког другог)" (РМС)] (ЕКор)).

Ж) ЛАЖ ЈЕ СРЕДСТво/оРУЂЕ/оРУЖЈЕ (пр. ...изванредан пример таквог коришћења лажи у цииьу стварања полифоније на филму (ЕКор); У тој спонтаности лакше барата лажима него истином (ЕКор); ...његово је оружје лаж и насиље (ЕКор)).

3) Да би лАж била уверљива, она мора опонашати истину у њеној основној особини, а то је необоривост. Све што се темељи на истини, сигурно је и поуздано: темељ - „1. део зида зграде испод површине тла који служи као ослонац зидовима; доњи слој, подлога” и ,фиг. оно што је битно, важно у нечему, оно на чему се нешто заснива, основ; полазни, главни елеменат нечега; принцип” (PMC). ЛАЖи, у том смислу, опонашају истину, па се тако издваја и метафора која ГЛаси ЛАЖ ЈЕ НЕСИГУРАН ТЕМЕљ (Пр. ...jер на злу и лажима ништа се вредно и дуготрајно не може саградити (ЕКор); ...морао [je] да призна да је фирма заснована на лажи (ЕКор); ...да су они у до тада непознатој мери лаж учинили фундаментом своје злочиначке политике (ЕКор)). Не само да је НЕСИГУРАН ТЕМЕљ већ је ЛАЖ И чИТава КОНСТРУКЦИЈА, оДНосНо ГРАЂЕВИНА (Пр. ...окарактерисали [су] као исконструисану лаж (ЕКор); које раздвајају зидови лажи (ЕКор); син. конструкција (Ћосић 2007)). 
3.1.4. Најзад, последња скупина метафора у вези је са односом САДРЖАВАњА. Тако се ЛАЖ МоЖе КОНЦеПтУаЛИЗОваТИ и Као САДРЖАТЕљ, и Као САДРЖАНИ ОБЈЕКАТ (СО) У САДРЖАТЕЉУ.

1) О ПоимањУ ЛАЖИ као САДРЖАТЕљА сведочи, понајПре, тиПично значење предлога $y$, које уједно важи и за концепт истине (Кликовац 2018: 114-115; Илић 2020: 284) (пр. изр. (у)гонити, утер(ив)ати и сл. некога у лаж (РСАНУ, РМС, РСЈ); ...рекао је да су то празне лажи чији је циљь да га дестабилизују (ЕКор)).

2) Са друге стране, ЛАЖ је САДРЖАНИ ОБЈЕКАТ, а обично су језичке јединице тада САДРЖАТЕљИ - речи, (зависне) реченице, па и цео текст (Кликовац 2000: 187; Илић 2020: 284-285). У тим ознакама садржана је не-стварност (тј. лАж).

а) „ЛАЖ” ЈЕ САДРЖАТЕЉ ЗА НЕ-СТВАРНОСТ, ПрИ чеМУ је ЛексеМа „ЛаЖ” оЗНаКа, а НЕ-СТВАРНОСТ - означено (пр. могао је да изрекне лажс (ЕКор); ...он дошаптава лажс (ЕКор); док декламује унапред научену лаж (ЕКор)).

б) Та ванјезичка не-стварност садржана у лексеми лаж може се језички изразити у оквиру исказа. Друкчије речено, као да се садржај лексеме може „извући" и експлицирати језичким средствима. ОдНосНО, САДРЖАНИ ОБЈЕКАТ (СО) ПреЛаЗИ ИЗ МањЕГ САДРЖАТЕЉА - речи У већИ - исКаз. ОТУДа: САДРЖАТЕЉ ЈЕ ИСКАЗ, ЛАЖ САДРЖАНИ ОБЈЕКАТ, Где се Под ИСКАЗОм најчешће подразумева зависна реченица (пр. ...ако не изговори лаж да је са још неколичином Срба починио злочин (ЕКор); Све што је тај човек рекао, обичне су лажи (ЕКор); ...у Србији се не живи лако али је лаж да се у њој скапава од глади (ЕКор)). ${ }^{10}$ Као што смо потцртали и у вези са истином, „[н]и сама реч или реченица не представља типичан конкретни појам, али је бар за степен ниже од [лАжи] на скали конкретностапстрактност, будући да се у усменом дискурсу реализује кроз звук (линеарно кроз време), а у писаном линеарно кроз простор, при чему њену експлицирану, вербализовану садржину можемо подвући и указати на њу конкретно" (Илић 2020: 285).

3.1.5. Овим појмовним метафорама дат је преглед концептуализације лАжи као ЕНТИТЕТА, а у преосталом делу рада осветлићемо део грађе који илуструје поимање ЛАЖи као ПоЈАвЕ.

3.1.6. У складу са лажи као апстрактном именицом, којој се у неким истраживањима са разлогом прилазило из угла теорије прототипа (Колман и Кеј 1981), чиме је показано да немају све лажи једнаке појавне и семантичке карактеристике, у нашем корпусу издваја се појмовна метафора која потврђује да је ЛАЖ ПОЈАВА КОЈА СЕ МОЖЕ РЕАЛИЗОВАТИ У РАЗЛИЧИТОМ СТЕПЕНУ (Пр. ТИМ изрекао 90-постотну лаж (ЕКор); Лаж је, међутим, зачињена Настићевим смехом, испадала само половична (ЕКор); Пола истине је цела лаж (ЕКор)). Та

${ }^{10}$ И шире од реченице, САДРжАТЕљ за ЛАЖ може бити и читав текст. Потврду за ово проналазимо у чињеници да се прича јавља као један од синонима лажи (Лалевић 2004; Ћосић 2007): причам ти причу, ловачка прича; тако и: урбана бајка, урбана легенда. Посебно је занимљив пример из ел. корпуса: Хитлерова политика у том смислу пуна је лажи, који може илустровати пример за метафтонимију (тј. метонимију унутар метафоре). Хитлерове речи/искази/говори пуни су лажи [метафора] $\rightarrow$ Хитлерова политика пуна је лажи [метонимија]. 
се ПОЈАВА ОСЕћА чУЛИМА (пр. Она је осећала лаж у сваком погледу (РСАНУ); ...чим се ма и најмање осети лаж (ЕКор); Горко једно осећање неправде, лажи, увлачило се у њега (ЕКор)) и НеретКо је НЕСТАЛНА, ПРОЛАЗНА И НИЈЕ ОД ОВОГА СВЕТА (пр. изр. где лаж руча ту не вечера („не задржава се дуго на истом месту”) (РСАНУ, РМС); изр. у лажи су кратке ноге / лаж кратке ноге има (,не може далеко стићи") (РСАНУ, РМС, РСЈ); изр. у лажи је плитко дно (,„лако се види шта је у њој") (РСАНУ, РМС); Сан је лажа, а Бог је истина (РСАНУ); син. варљивост (Ћосић 2007)). Као и У случају ИСТИНЕ, У ЛАЖ ВЕРУЈЕМО ИЛИ НЕ ВЕРУЈЕМО (пр. ...ja лично верујем у ту његову лаж као у највећу истину (ЕКор); ...да те у ту лаж убиједе (ЕКор); И многи су поверовали у ову лаж (ЕКор); син. лажан - „значи особину речи, предмета, документа [...] којима не треба веровати, који су од лажи, у којима нема истине”; непоуздан - „што не улива поуздање”, тј. у шта не можемо веровати (Лалевић 2004)).

a) Конкретнија појавност лАжи огледа се у метафори ЛАЖ ЈЕ ЗЛочин. Сa овом метафором у вези је и наведена ЛАЖ ЈЕ РОБА КОЈА ИМА ЦЕНУ, аЛИ коју пЛаћамо када је продамо. ШТО ЈЕ ЛАЖ ТЕЖА, ЦЕНА ЈЕ ВЕЋА. ОДНОсНО, ВЕЋИ ЗЛОЧИН ДОНОСИ ВЕЋУ КАЗНУ (пр. Ето Како се мора платити за лаж (ЕКор); ...јер се лаж кажнава (ЕКор); ...креатора нико не може оптужити за лаж (ЕКор)).

б) Следећа конкретизација ЛАЖИ као пОЈАВЕ јесте ЛАжљИвОст ЈЕ БОЛЕСт, тј. СКЛОНОСТ КА ЛАЖИМА ЈЕ БОЛЕСТ (пр. Урођена и неизлечива лажљьвост господина Милића, доводила је у сумьу све оно што је говорио (РСАНУ); патолошки лажов [патолошки - „који спада у науку о болестима, који се тиче науке о болестима; болестан" (Вујаклија $\left.\left.{ }^{9} 2006\right)\right]$ (ЕКор)).

в) Најзад, у овој групи кристалише се и метафора ЛАж ЈЕ ФИзичкА СИЛА (пр. А уздрмала га је једна лаж у темељу новог друштва (ЕКор); Лажи ће те нагнати да пожелиш да се убијеш (ЕКор); Треба жестоку лаж... страшну и јаку лаж (ЕКор)), а она МОЖЕ НАНЕТИ ПОВРЕДЕ (пр. Какве погубне лажи (ЕКор); Највише ме боле лажи (ЕКор); Али чувајмо се лажи (ЕКор); Смртоносна обмана (ЕКор)).

\section{2. ЛАж у Асоцијативном и Обратном асоцијативном речнику српског} језика. Као и истина, и лаж је један од стимулуса у Асоиијативном речнику српског језика (2005), а такође се јавља и као реакција на многе друге стимулусе, што потврђују подаци из Обратног асоиијативног речника (2011). Најпре на основу речи-реакција на стимулус лаж покушаћемо да утврдимо поимање лажи кроз асоцијативну призму говорника српског језика, а ради потпуније слике испитаћемо и податке које нуди Обратни асочијативни речник.

За доношење релевантних закључака најбитније су речи-реакције са највећим бројем јављања. Отуда ћемо их, према датим фреквенцијама у Acoцијативном речнику, поделити и овде у три групе:

I: истина (192), неистина (73), превара (46), обмана (15), неповерење (13);

II: кратке ноге; глупост, ноге; лоше; бол, издаја; неискреност, политика; зло;

III: лицемерје, неправда, потреба, срамота, страх, велика; боли, лагати, лажов, мана, ружно; безобразлук, ирвенило, често, човек, љутња, неопростиво, презир; грех $[\ldots]$ 
Из прве групе примера потврђујемо постојање односа антонимичности између лексема истина и лаж, будући да је убедљиво најфреквентнија асоцијација на лаж-истина. Следи њен синоним, неистина, у чијој семској структури нема интенционалности (већ је реч о не-стварности, ономе што нuје per se), а потом долазе и други синоними: превара, обмана. Ова два синонима подразумевају намеру да се некоме нанесе штета - у вербалном или другом смислу; за такав поступак обично се испашта, те ЛАЖ/ПРЕВАРУ разумемо као зЛочИН или ГРЕХ. Реакција неповерење води до метафоре да је ЛАЖ ПОЈАВА У кОЈУ ВЕРУЈЕМО ИЛИ HE BEPУJEMO.

Реакције из друге групе примера знатно су ређе, али довољне су да наговесте неке појмовне метафоре до којих смо већ дошли у анализи грађе. Тако кратке ноге, глупост, ноге у вези су са метафором ЛАЖ ЈЕ ОСОБА, а реакција кратке ноге упућује још и на ЛАЖ која ЈЕ КРАТкотРАЈНА. Асоцијација лоше потцртава да се ради о негативном члану антонимског пара, ${ }^{11}$ што је у вези са свим метафорама које одражавају поимање ЛАЖи у негативном светлу: живи у ПРостоРу МРАЧНОГ И ПРЉАВОГ, ЧУДОВИШТЕ, МОЖЕ ДА ПОВРЕДИ; НЕСТАЛНА, НЕСИГУРНА ГРАЪЕВИНА, итд. Реакција бол потврђује да ЛАЖ МОЖЕ ПОВРЕДИТИ иЛИ да се ОСЕЋА чУЛИМА. У овој групи интересантна је још и реакција политика, која упућује на помињани домен друштвеног живота. ${ }^{12}$

Најзад, летимично ћемо се осврнути на трећу групу примера, будући да се у њој налазе реакције које спадају у ред најмање фреквентних. Лицемерје упућује на превртљивост лажи, тј. ЛАЖ ЈЕ ЕНТИТЕТ кОЈИ СЕ ТРАНСФОРМИШЕ. Неправда је у синонимичном или каквом последичном односу са лажи, ако је разумемо по аналогији истина : правда $\approx$ неистина : неправда. ЛАЖ ЈЕ ВЕЛИКА (велика) и иЗАЗИвА СТРАХ (страх). Занимљива је и реакција црвенило, у чијој је основи меТОНИМИјсКа форМУЛа ЕМОЦИЈА - ФИЗИОЛОШКА РЕАКЦИЈА ДО КОЈЕ ЕМОЦИЈА ДОводи. Лаж последично може довести до осећања стида (УзРок - ПосЛЕдицА), што даље узрокује црвенило у лицу. Реакције безобразлук, грех, неопростиво упућују на метафору лАж Је зЛочин.

Обратни асоцијативни речник показује да се лаж нашла као реакција следећим стимулусима - наводимо само оне на које се реакција лаж јавила више од десет пута: истина (292), лицемерје (108), неповерење (81), трач (60), лагати (51), медији (40), рекао (38), завера (33), обећање (32), политика (26), новине (20), демократија (14), нос (13), рећи (11).

Лицемерје, као што смо навели, упућује на дволичност, превртљивост, те на метафору ЛАЖ ЈЕ ЕНТИТЕТ КОЈИ СЕ ТРАНСФОРМИШЕ, а неповерење и обећање

\footnotetext{
${ }^{11}$ Да је реч о минус-антониму, потврђује још један податак: у РСАНУ лаж има много више деривата (преко 90) него истина (око 30). (Истраживања су показала да маркирани чланови антонимског пара - тзв. минус-антоними - имају развијенију деривацију, док немаркирани чланови имају развијенију полисемију; исп. Драгићевић $\left.{ }^{2} 2010: 278.\right)$

${ }^{12}$ Резултати асоцијативног теста који смо за потребе овог истраживања спровели са 110 ученика трећег и четвртог разреда Четрнаесте београдске гимназије показали су да је прототипични ГОВОРНИК ЛАЖИ ПОЛИТИЧАР, ДОК је ПротоТИПИЧНИ ГОВОРНИК ИСТИНЕ - ПРИЈАТЕљ (ИЛИћ 2018).
} 
На метафору - ЛАЖ ЈЕ ПОЈАвА У колу (НЕ) ВеРУЈЕмо. На стимулус трач, лаж је чак 60 пута реакција. У РМС проналазимо: трач - „оговарање, клеветање, клевета, лаж; брбљање", те закључујемо не само да је ово синоним лажи већ и да ПоТВрђУје МеТафорУ ЛАЖ ЈЕ САДРЖАНИ ОБЈЕКАТ У ИСКАЗУ КОЈИ НЕ ОДГОВАРА СТВАРности. Исто се односи и на стимулусе: рекао, рећи. Затим, медији, политика, новине, демократија указују на домен друштвеног живота у коме се лАж најчешће/ типично јавља. Стимулус завера, на који је лаж 33 пута реакција указује на лАж која ЈЕ НЕПРИЈАТЕљ: завера - „тајни договор против кога или чега” (РМС; курзив је наш - В. И.). Најзад, на стимулус нос, лаж ће такође бити реакција, што потиче од лика дечјег романа Пинокија, коме нос порасте сваки пут када изрекне лаж. Иако таква физиолошка реакција постоји само на нивоу фантастичног у овом прецедентном тексту, метонимијска веза заснована на формули ЕмоцијА ФИЗИОЛОШКА РЕАКЦИЈА ИПаК се Успоставља. МеђУТИм, овде можемо ГовориТи и о синегдохи, која се тиче односа ПОЈЕдИНАчНО - ОПШТЕ (Пинокио - сваки човек).

На основу реакција на стимулус лаж, као и на основу стимулуса на које се као реакција јавља лаж у достатном броју примера, можемо извести метафорички сценарио концептуализације лАжи у асоцијацијама говорника српског језиКа: ЛАЖ ЈЕ ЗЛА ПОЈАВА У КОЈУ (НЕ) ВЕРУЈЕМО, ОНА ЈЕ ЧУДОВИШНА, НЕПРИЈАТЕЉСКА И МОЖЕ ДА ПОВРЕДИ. ТРАНСФОРМИШЕ СЕ, ВЕЛИКА ЈЕ И ИЗАЗИВА СТРАХ. МОЖЕ СЕ САКРИТИ У ИСКАЗУ ИЛИ ИМАТИ ЛИК ЧОВЕКА; КРЕЋЕ СЕ У СФЕРИ ЈАВНОГ ДРУШТВЕНОГ животА.

\section{4. Закључак о концепту лАжи у савременом српском језику}

4.1. Концептуална анализа примера из корпуса показала је да се на генеричком нивоу лАж концептуализује као 1) ЕНтитет и као 2) поЈАВА.

(1) Важна карактеристика ЛАЖИ Као ЕНТИТЕТА јесте СПОСОБНОСТ ТРАНСФОРМАЦИЈЕ. ЛАЖ СЕ НАДМЕЋЕ У ТРЦИ СА ИСТИНОМ, аЛИ МОЖЕ ЗАУЗИМАТИ И КРАЈњУ ГРАНИЦУ ИСТОГ КОНТИНУУМА, НА ЧИјОј је ДРУГОЈ КРАЈНОСТИ ИСТИНА. ЧОВЕК се У ПОТРАЗИ ЗА ИСТИНОМ УДАљАВА ОД ЛАЖИ. БИТИ ДАљЕ ОД ЛАЖИ ЈЕ БИТИ БЛИЖЕ иСТИНИ. Даља конкретизација ЕНТИТЕТА и овде је У видУ ЖИвОГ БИЋА, МАТЕРИЈЕ И ПРЕДМЕТА.

(1.1) Метафора ЛАЖ ЈЕ ЖИВО БИЋЕ даље се грана На чОВЕКА/ОСОБУ, чУДОВИШТЕ, ПТИЦУ И БИљКУ. ОбИЧНО ИМА НЕГАТИВНЕ ОСОБИНЕ И ЖИВИ У ПРОСТОРУ МРАЧНОГ И ПРЉАВОГ; ЛАЖ ЈЕ И ВОЪА И ГОСПОДАР, АЛИ И НЕПРИЈАТЕЉ. СХВаЋЕНа КаО МАТЕРИЈА, ЛАЖ ЈЕ ТЕЧНОСТ, МУТНА И ПЛИТКА. ДОБИЈЕ ЛИ НЕШТО ОД ПРОЗИРНОСТИ, НЕЋЕ ОПСТАТИ. ТаКОђ , ОБИЧНО ЈЕ ХРАНА, КОЈА ЈЕ ЗАЧИЮЕНА, СЛАНА, РЕЪЕ СЛАТКА, ЧЕСТО МАСНА. СЕРВИРА СЕ И МИ ЈЕ ГУТАМО. КАДА СУ ЛАЖИ СТАРЕ, ОНЕ СУ БАЈАТЕ. ПореД ОВОГа, ЛАЖ ЈЕ И ПРЕДМЕТ, КОЈИ ЈЕ САКРИВЕН ИЛИ СЕ НАЛАЗИ ПРЕД НАМА. ОНа има КарактеристиКе предмеТНостИ - старост (СТАРА ИЛИ НОВА), величина (ВЕЛИКА ИЛИ МАЛА), $n p u n a \partial н о с т$ (ПОСЕДУЈЕМО ЈЕ) И бој $($ (ШАРЕНА; БЕЛА ИЛИ ЦРНА). ТАЈ 
ПРЕДМЕТ СЕ ПРОИЗВОДИ У ФАБРИЦИ, Па ОТУДа ЛАЖ ЈЕ РОБА КОЈА ИМА ЦЕНУ. ЛАЖ ЈЕ И МАСКА/ПЛАШТ, ОРУЪЕ ИЛИ ОРУЖЈЕ. ТаКОђЕ, ЛАЖ ЈЕ НЕСИГУРНА ГРАЂЕВИНА ЈЕР ЈЕ ЊЕН ТЕМЕЉ НЕСИГУРАН. ОНа је САДРЖАТЕЉ, а КаДа је САДРЖАНИ ОБЈЕКАТ, НАЛАЗИ СЕ ТИПИЧНО У ИСКАЗУ ИЛИ У РЕЧИ.

(2) На општем метафоричком нивоу, поред ЕНТИТЕТА, јавља се и концептуаЛИЗаЦИја ЛАЖИ КаО ПОЈАВЕ. ОНА СЕ РЕАЛИЗУЈЕ У РАЗЛИЧИТОМ СТЕПЕНУ, ОСЕЋАМО ЈЕ ЧУЛИМА И ПРОЛАЗНА ЈЕ. У ФУ ВЕРУЈЕМО ИЛИ НЕ ВЕРУЈЕМО. ЛАЖ ЈЕ ЗЛОЧИН И ФИЗИЧКА СИЛА КОЈА МОЖЕ ПОВРЕДИТИ, ПА ОД ФЕ БОЛУЈЕМО.

\section{5. Закључак о концептуализацији апстрактума истина и лаж у савременом српском језику}

5.1. Испитивање концепата утемељених у етимологији именица истина и лаж указало је да је истинА стварност, која постоји као датост, изван наше воље и активности, док је лАж безизузетно производ људског деловања. Лаж, дакле, није само пука супротност истини, којом би се означила нека не-стварност. Лаж подразумева њено свесно, намерно извртање, типично са циљем да саговорник У њУ поверује. ИстИНА је СТАТИЧНА, а ЛАЖ ДИНАМИЧНА. И лексикографи Речника САНУ уочавају ову семантичку неравнотежу међу члановима нашег антонимског пара: сема интенционалности нераскидиво је скопчана са семантиком именице лаж, коју истина нема, а та чињеница онемогућава успостављање односа праве антонимије међу њима. Отуда је именици истина једини прави антоним неистина, док се лаж, са једном есенцијалном семом више - може сматрати њеним неправим антонимом (Илић 2020: 278, 280).

5.2. Уколико конфронтирамо концепте истинЕ и ЛАЖи до којих смо дошли, можемо закључити следеће: 1) појмовне метафоре са виших нивоа на скали конкретно-апстрактно у потпуности се подударају (ЕНтитет - поЈАВА); 2) као ЕНтитЕти, оба појма имају такође идентичне конкретизације (живо БиЋЕ - поЈАВА - ПРедмЕт); 3) разлике се јављају само на најнижим нивоима конкретности, где су задржане и неке подударности; 4) истиНА ЈЕ ОСОБА чешће СА ПОЗИТивним ОСОБИНАМА, ЛАЖ СА НЕГАТИВНИМ, 5) ЛАЖ ЈЕ ЧУДОВИШТЕ И НЕПРИЈАТЕЉ, ДОК ИСТИНА НеМа оваКВо ПОИМање; 6) ИСТИНА ЈЕ ДУБОКА И БИСТРА ТЕЧНОСТ, ЛАЖ ПЛИТКА И МУТНА; 7) ИСТИНА ЈЕ ГОРКА, ЛАЖ СЛАТКА ИЛИ ПРЕСОЉЕНА; 8) ИСТИНА ЈЕ СТАМЕНА ГРАЂЕВИНА, ЛАЖ НЕСИГУРАН ТЕМЕЉ; 9) ИСТИНА ЈЕ ПРОЗИРНА, ЛАЖ ОБОЈЕНА; 10) ИСТИНА ЈЕ СВЕТЛОСТ, ЛАЖ ЈЕ У ТАМИ; 11) ИСТИНА ЈЕ ВЕЧНА, ЛАЖ ПРОЛАЗНА.

5.3. На основу концептуализација ових апстрактума можемо закључити да су истинА и лАж две стране исте медаље, при чему једна има јединствен лик, док друга може имати бесконачно много варијанти, јер се једна истина може представити на небројено много лажних начина. Представљена анализа само је један поглед на истину и лаж, који не негира друге приступе и другачије анализе, већ заједно са њима, синергично и комплементарно, доприноси бољем и темељнијем разумевању овог предмета истраживања. 


\section{ЛИТЕРАТУРА ${ }^{13}$}

Адха 2020: Ahmad Adha, "Indonesians Do Not Believe in Lying: New Results of Replicating Coleman and Kay's Study", Pro-Fil, An Internet Journal of Philosophy, Vol. 21, No. 1, p. 11-23 (Доступно на: www.phil.muni.cz/journals/index.php/ profil/article/view/2067).

Буслајев 21867: Фёдор Буслаев, O преподовании отечественнаго языка, Москва: Издан1е братьевъ Салаевыхъ.

Ван Дитмарх и др. 2020: Hans van Ditmarsch, Petra Hendriks, Rineke Verbrugge, "Editors' Review and Introduction: Lying in Logic, Language, and Cognition", Topics in Cognitive Science, 12 (2020), p. 466-484.

Гентнер/Баудл 2008: Dedre Gentner and Brian Bowdle, „Metaphor as Structure-Mapping", in: The Cambridge Handbook of Metaphor and Thought (ed. by Raymond W. Gibbs, jr.), Cambridge: Cambridge University Press, p. 109-128.

Драгићевић 2010: Рајна Драгићевић, Лексикологија српског језика, Београд: Завод за уџбенике.

Еванс/Грин 2006: Vyvyan Evans and Melanie Green, Cognitive Linguistics: An Introduction, Edinburgh: Edinburgh University Press.

Ејчисон 1987: Jean Aitchison, Words in the Mind, An Introduction to the Mental Lexicon, Oxford-Cambridge: Basil Blackwell.

Илић 2018: Валентина Илић, „Концептуализација истине и лажи у асоцијацијама наших ученика”, Свет речи, 45-46, Београд: Друштво за српски језик и књижевност Србије, стр. 14-18.

Илић 2020: Валентина Илић, „Апстрактуми истина и лаж у савременом српском језику: концептуализација истине (когнитивнолингвистички приступ)", Кюижевност и језик, LXVII/2, стр. 273-290.

Кант/Констан 2008: Imanuel Kant, Benžamen Konstan, Pravo na laganje, Beograd: Službeni glasnik.

Кевечеш 2010: Zoltán Kövecses, Metaphor: A Practical Introduction, New York: Oxford University Press.

Кликовац 2000: Duška Klikovac, Semantika predloga, studija iz kognitivne lingvistike, Beograd: Filološki fakultet.

Кликовац 2004: Duška Klikovac, Metafore u mišljenju i jeziku, Beograd: Biblioteka XX vek.

Кликовац 2018: Душка Кликовац, Српски језик у светлу когнитивне лингвистике, Београд: Друштво за српски језик и књижевност Србије.

Колман/Кеј 1981: Linda Coleman and Paul Kay, „Prototype Semantics: The English Word Lie", Language, Vol. 57, No. 1, p. 26-44.

Лејкоф/Џонсон 1980: George Lakeoff and Mark Johnson, Metaphors We Live By, Chicago - London: The University of Chicago Press.

\footnotetext{
${ }^{13}$ Наведена је литература цитирана у оба дела овог истраживања.
} 
Лејкоф/Џонсон 1999: George Lakeoff and Mark Johnson, “The anatomy of complex metaphor", in: Philosophy in the Flesh. The Embodied Mind and Its Challenge to Western Thought, New York: Basic Books, p. 60-73.

Мршевић-Радовић 2008а: Драгана Мршевић-Радовић, „О антропоцентризму у српској фразеологији (,лажљив”, „лагати” у синхронији и дијахронији)", Книжевност и језик, LV: 1-2, стр. 47-56.

Мршевић-Радовић 2008б: Драгана Мршевић-Радовић, Фразеологија и национална култура, Београд: Друштво за српски језик и књижевност Србије.

Ортега и Гасет 2010: Hose Ortega i Gaset, „Dve velike metafore”, Mostovi, 38/147, sv. 1, str. 212-222.

Расулић 2004: Katarina Rasulić, Jezik i prostorno iskustvo: konceptualizacija vertikalne dimenzije u engleskom $i$ srpskohrvatskom jeziku, Beograd: Filološki fakultet.

Свитсер 1987: Eve Sweetser, "The definition of lie: an examination of the folk models underlying a semantic prototype", in: Cultural models in language and thought (ed. D. Holland, N. Quinn), Cambridge: Cambridge University Press, p. 43-66.

Свитсер 1990: Eve Sweetser, From Etymology to Pragmatics. Metaphorical and Cultural Aspects of Semantic Structure. Cambridge: Cambridge University Press.

Свифт 2002: Џонатан Свифт, Гуливерова путовања, Београд: Источник.

Слијепчевић/Новокмет 2012: Светлана Слијепчевић и Слободан Новокмет, „О концептуализацији појмова истина и лаж у српском језику од 19. до 21. века", у: Време и история в славянските езици, литератури и култури, сборник с доклади от Единадесетите национални славистични четения, 19-21 април 2012, Том I, Езикознание (съст. Бурова, А. и др.), София: Университетско издателство „Свети Климент Охридски”, 165-173.

Станишић 2012: Вања Станишић, „О северним индоевропским везама албанског језика", у: Praslovanska dialektizacija v luči etimoloških raziskav, Ob stoti obletnici rojstva akademika Franceta Bezlaja (ur. Furlan, M., Šivic-Dular, A.), Ljubljana: Inštitut za slovenski jezik Frana Ramovša ZRC, SAZU, 199-211.

Унгерер/Шмид 1996: Friedrich Ungerer and Hans-Jörg Schmid, An Introduction To Cognitive Linguistics, Edinburgh Gate, Harlow: Longman.

Черњејко 1997: Людмила Олеговна Чернейко, Лингво-философский анализ абстрактного имени, Москва: Филологический факультет.

Шкембер 2012: Ante Škember, ,Istina u filozofiji i objavi. Poimanje istine u filozofiji i kršćanstvu", Nova prisutnost, 10/1, str. 105-113.

\section{ИЗВОРИ}

Вујаклија ${ }^{92006: ~ М и л а н ~ В у ј а к л и ј а, ~ Л е к с и к о н ~ с т р а н и х ~ р е ч и ~ и ~ и з р а з а, ~ Б е о-~}$ град: Просвета.

Драгићевић и др. 2011: Рајна Драгићевић, Предраг Пипер, Марија Стефановић, Обратни асоиијативни речник српскога језика. Део 2, Од реакиије ка стимулусу, Београд: Београдска књига. 
EKop: http://www.korpus.matf.bg.ac.rs, Korpus savremenog srpskog jezika, Matematički fakultet Univerziteta u Beogradu.

ЕССЯ 1974-: Этимологический словарь славянских языков: праславянский лексический фонд, Институт русского языка РАН, Москва: Наука.

OEP: https://www.etymonline.com, Online Etymology Dictionary [of Modern English].

Лалевић 2004: Miodrag S. Lalević, Sinonimi i srodne reči srpskohrvatskoga jezika, Beograd: Nolit.

Пипер и др. 2005: Предраг Пипер, Рајна Драгићевић, Марија Стефановић, Асоцијативни речник српскога језика. Део 1, Од стимулуса ка реакцији, Београд: Београдска књига.

PMC I-VI: Речник српскохрватскога књижевног језика, Нови Сад: Матица српска, 1967-1976.

PCAНУ I-XXI: Речник српскохрватског књижевног и народног језика, књ. VIII и XI, Београд: Институт за српски језик САНУ, 1959-.

PCJ: Речник српскога језика, Нови Сад: Матица српска, 2007.

Скок 1971-1974: Petar Skok, Etimologijski rječnik hrvatskoga ili srpskoga jezika, I, II, IV, Zagreb: JAZU.

Ћосић и др. 2007: Павле Ћосић и сарадници, Речник синонима и тезаурус српског језика, Београд: Корнет.

Валентина М. Илич

\section{АБСТРАКТНЫЕ ИМЕНА ИСТИНА И ЛОЖЬ В СОВРЕМЕННОМ СЕРБСКОМ ЯЗЫКЕ: КОНЦЕПТУАЛИЗАЦИЯ ЛЖИ \\ (когнитивно-лингвистический подход)}

Резюме

Эта статья представляет собой вторую часть исследования в котором был проведен анализ абстрактных существительных имен истина и ложь, с точки зрения когнитивной лингвистики, на базе современного сербского языка, т.е. методом концептуального анализа. Основная часть статьи - концепт лжи, представлен концептуальными метафорами, сгруппированными на различных уровнях общности. В самом конце делается вывод и выделяются ключевые характеристики формирования этого понятия в нашей когнитив- 
ной системе. Затем сравниваются концепты истины и лжи в современном сербском языке и делается вывод о природе этих антонимов.

Ключевые слова: ложь, истинА, абстрактное имя, концепт, концептуальная метафора, концептуальный анализ. 